\title{
SANTA MORTE, A SANTA ESQUELÉTICA NO MÉXICO E NOS ESTADOS UNIDOS
}

\author{
Saint Death, the Skeleton Saint in \\ Mexico and in the United States \\ R. Andrew Chesnut* \\ Tradução: Karina Kosicki Bellotti**
}

\begin{abstract}
RESUMO
Este artigo traz algumas considerações retiradas de uma pesquisa mais ampla sobre as razões do aumento da popularidade do culto à Santa Morte no México e nos Estados Unidos, desde o início dos anos 2000. De uma prática oculta, desconhecida de boa parte dos mexicanos, transformou-se em um crescente culto público que contabiliza milhões de devotos nos dois países. O texto analisa a evolução do culto, do período colonial hispânico até os dias atuais, e, por meio de entrevistas, mídia impressa e pesquisa de campo, explora os diferentes atributos conferidos à santa por uma grande gama de devotos, de donas de casa a traficantes, em meio a um contexto conturbado de crescente recessão econômica e violência urbana.
\end{abstract}

Palavras-chave: catolicismo popular; México; Estados Unidos.

\begin{abstract}
This article brings some reflections on considerations from a wider research on the reasons for the growth of popularity of the cult of Saint Death in Mexico and United States, since the early 2000s. From an occult practice, unknown to most Mexicans, it became a burgeoning public cult that counts millions of devotees in both countries. The text

* Professor titular do Departamento de Estudos Religiosos e Bishop Walter F. Sullivan Chair em Estudos Católicos, Virginia Commonwealth University. Autor dos seguintes livros: Born Again in Brazil: The Pentecostal Boom and the Pathogens of Poverty (Rutgers University Press, 1997), Competitive Spirits: Latin America's New Religious Economy (Oxford University Press, 2003) e Devoted to Death: Santa Muerte the Skeleton Saint (Oxford University Press, 2011).

** Professora adjunta do Departamento de História da Universidade Federal do Paraná.
\end{abstract}


analyses the evolution of the cult, from Hispanic Colonial period until the current days, and through interviews, press media and field research, it explores the different attributes given to the Saint by a wide range of devotees, from housewives to drug dealers, in a troubled context of growing economic recession and urban violence.

Key-words: popular Catholicism; Mexico; United States.

\section{Chamado pela Senhora Ossuda, a Santa Morte}

Algumas pessoas se tornam devotas por iniciativa própria, apelando para a Santa Morte sob recomendação de amigos ou de familiares. Outros recebem um chamado ou uma visita inesperada da Magrinha (la flaquita, um dos seus vários apelidos), no qual ela se oferece para resolver seus problemas. Foi nesse contexto que, no início da primavera de 2009, a Ossuda (la huesuda, outro apelido conhecido) apareceu no meu laptop e meu chamou para contemplá-la. Mais especificamente, foi a notícia de um ataque militar contra ela na fronteira entre os Estados Unidos e o México que me levou a substituir a figura de Guadalupe pela imagem de algo que parecia, à primeira vista, a sua antítese, uma espécie de anti-Virgem. No final de março, o exército mexicano demoliu perto de quarenta santuários da Santa Morte na fronteira mexicana com o Texas e a Califórnia, na sua maioria na periferia de Tijuana e Nuevo Laredo. Eu me perguntava o que teria feito a Santa Morte para merecer um ato tão agressivo de sacrilégio em seus lugares santos, perpetrado pelo governo mexicano, que a declarou um inimigo de Estado?

Este texto traz algumas considerações sobre uma pesquisa mais ampla, que buscou desvendar por que em menos de uma década a devoção à santa cresceu a tal ponto que sua popularidade ofusca a de outras santas no México, com exceção de Guadalupe. Seu culto se transformou de uma prática oculta, desconhecida de boa parte dos mexicanos, para se tornar um crescente culto público que contabiliza milhões de devotos no México e nos Estados Unidos. 


\section{A Morte encontrada}

Como seu nome indica, Santa Morte é uma santa popular mexicana que personifica a morte. Seja na forma de uma estátua de gesso, em uma vela votiva, um medalhão de ouro ou um cartão de oração, ela é representada como uma Ceifadora, manejando a mesma foice e usando uma mortalha semelhante à do Ceifador. Diferente de outros santos, que foram canonizados pela Igreja Católica, os santos populares são espíritos de mortos que são considerados santos pelos seus poderes milagrosos. No México e na América Latina em geral, tais santos, como Nino Fidencio, Jesus Malverde, Maximon e San La Muerte (a similar argentina da Santa Morte) mobilizam uma ampla devoção e frequentemente apelam para mais do que os santos oficiais.

A grande maioria dos santos populares, diferente dos oficiais, nasceu e morreu em solo latino-americano. Nino Fidencio, por exemplo, era um curandeiro popular no início do século XX no México, enquanto Pedro Batista liderou uma comunidade religiosa no interior do Brasil durante $\mathrm{o}$ mesmo período. Assim, os santos populares são unidos aos seus devotos pela nacionalidade e frequentemente pela localidade e classe social. Um vendedor de rua da Cidade do México explicou o apelo da Santa Morte: "Ela nos entende porque é uma pessoa de gênio forte (cabrona) como nós". Em contraste, os mexicanos nunca se refeririam à Virgem de Gaudalupe como megera. Onde a Ossuda se difere de outros santos populares, incluindo os santos esqueléticos da Argentina (San La Muerte) e da Guatemala (Rey Pascual), é que, para a maioria de seus devotos, ela é personificação da morte em si, e não de um ser humano morto.

O seu próprio nome, Santa Morte, diz muito sobre sua identidade. La muerte - a morte - é um substantivo feminino, assim como em todas as línguas românicas. Por isso, alguns observadores casuais da Branquinha atribuíram erroneamente a sua identidade feminina por conta do substantivo "La muerte". Entretanto, o fato de os dois santos da morte da Argentina e da Guatemala serem figuras masculinas aponta para outras explicações sobre a identidade feminina da santa mexicana. Em todo caso, ela e San La Muerte são os únicos santos nas Américas que incluem a palavra "morte" em seus nomes. Tanto para devotos como para os descrentes, é óbvio que o olhar vazio da santa esquelética é o olhar da morte. 
A palavra "Santa", a primeira parte do seu nome, é também reveladora. A Santa Morte é primeira e principalmente uma santa não oficial que cura, protege e livra seus devotos de seus destinos após a morte. Devotos costumam chamá-la de "Santíssima Morte" em rituais como o rosário. Assim, seu nome, Santa Morte, e sua miríade de apelidos revelam nitidamente sua identidade como santa popular que personifica a morte.

Nenhuma introdução à Santa Morte ficaria completa sem uma breve consideração sobre uma de suas mais peculiares características - sua identidade de gênero. Enquanto os santos populares são abundantes nas Américas e outros esqueletos sobrenaturais operam milagres na Guatemala e na Argentina, a Santa Morte permanece como a única santa da morte, do Chile ao Canadá. Sua forma esquelética assexuada não contém nenhum traço de feminilidade. São seus trajes e, em menor medida, seu cabelo que definem esta santa como mulher. Os devotos e fabricantes de imagens produzidas em massa da Ossuda comumente a vestem como freira, Virgem, noiva ou rainha. Túnicas medievais vermelhas e pretas, véus de noiva brancos e túnicas de cetins coloridas normalmente cobrem seu corpo esquelético, deixando à vista somente suas mãos, pés e face ossudos.

Tal como os santos da morte, San La Muerte e Rey Pascual, a Madrinha exibe um típico crânio calvo. Contudo, seguindo a trilha de uma grande pioneira devocional, Enriqueta Romero (carinhosamente conhecida como Dona Queta), muitos devotos adornam suas estatuetas com perucas pretas e castanhas. Aliás, uma devota empreendedora dirige uma próspera loja na Cidade do México onde devotos trazem suas estatuetas para serem vestidas e penteadas para que se pareçam com a Menina Bonita (la nina bonita, outro de seus codinomes). Porém, mais do que apenas uma menina bonita, a Santa Morte é principalmente a Poderosa (la dama poderosa), cujas habilidades milagreiras fizeram dela o mais potente dos santos populares mexicanos e uma rival da padroeira nacional, Guadalupe.

\section{Origens}

As origens do culto à Santa Morte remetem a diferentes matrizes. Enquanto sua figura pode evocar uma versão feminina do Ceifador na cultura 
americana e europeia ocidental (Grim Reaper), com raízes no catolicismo medieval, na cultura espanhola católica a morte é identificada com a figura de La Parca. Já na cultura mexicana, a santa esquelética seria uma versão adaptada de uma deusa indígena da morte, geralmente asteca ou maia. Para muitos mexicanos, as realidades da história indígena e os mitos do nacionalismo convergem para dar à Irmã Branca um nascimento nativo no México Pré-Colombiano.

A versão mais comum da identidade indígena da santa remete às suas supostas origens astecas, isto é, a deusa da morte Mictecacihuatl, que, juntamente com seu marido, Mictlantecuhtli, governava o submundo, Mictlan. Assim como a Ossuda, o casal mortífero era representado como esqueletos ou corpos humanos com crânios no lugar de cabeças. Os astecas não somente acreditavam que os que morriam de causas naturais acabavam em Mictlan, como também evocavam os poderes sobrenaturais dos deuses para causas terrenas. Com a perseguição empreendida pelos conquistadores espanhóis em relação à religião indígena, os espanhóis tornaram clandestina a devoção ao casal asteca e forçaram o sincretismo da crença com o catolicismo. Assim, de acordo com essa versão, é a deusa Mictecacihuatl que ressurgiu publicamente no santuário de Dona Queta, em 2001. Sua túnica e vestido em estilo espanhol e seus acessórios europeus, a foice e as balanças de justiça são uma fachada que cobriria sua verdadeira identidade asteca.

Outra versão é de que a Menina Branca seria de origem Purepecha, o maior grupo indígena no Estado de Michoacan, que nunca foram conquistados pelos vizinhos astecas. Em entrevista, o líder de culto da Santa Morte Vicente Perez Ramos traçou as origens da santa a Santa Ana Chapitiro, uma pequena cidade fora de Patzcuaro, onde um dos santuários mais decorados de Santa Morte se situa. Don Vicente alega que a santa da morte nasceu no século XVI, filha de um casal Purepecha de Santa Ana Chapitiro. Ela possuiria o tamanho de uma mulher adulta, com uma compleição suave e cabelo castanho. Com medo de que os espanhóis a roubassem, o casal manteve a filha trancada em sua cabana.

Já os acadêmicos traçaram as origens da santa à Europa ocidental medieval. A antropóloga mexicana Katia Perdigon Castañeda, por exemplo, escreve que: "a história do conceito atual de morte e sua iconografia, refletida na contemporânea Santa Morte, estão mais relacionadas à religião judaico-cristã (com o catolicismo em particular) do que com as vozes esquecidas 
e desconhecidas dos vencidos, ou seja, dos povos pré-hispânicos"'. David Romo e outros localizam especificamente a gênese da santa na figura do Ceifador do catolicismo europeu medieval, por conta da peste bubônica, que tornou a morte uma presença constante e familiar no século XIV. Foi nesse período, no qual ao menos um terço dos europeus foi levado pela doença, que a morte apareceu personificada pela primeira vez como a figura esquelética conhecida até hoje. Pintores, escultores e padres começaram empregar a representação esquelética da morte em seu trabalho.

A figura também foi empregada pelo clero espanhol nas Américas. Alguns grupos indígenas, como os maias no Estado de Chiapas e Guatemala, e os Guaranis na Argentina e Paraguai, transformaram a figura da morte em uma santa e, a partir de suas próprias tradições de ossos ancestrais sagrados, interpretaram o cristianismo por meio de seus filtros culturais. Isso é mais evidente na Guatemala e em Chiapas, onde o franciscano espanhol do século XVI São Pascual Bailon foi sincretizado com a religião maia e tornou-se popularmente, mas não oficialmente, representado como Rey Pascual, um esqueleto com uma coroa em cima de seu crânio. Embora nunca tenha visitado os maias do México e da Guatemala em vida, surgiu a crença de que ele tenha aparecido em uma visão para um maia em torno de 1650, no meio de uma praga virulenta que o frei teria ajudado a encerrar ${ }^{2}$. Durante o período colonial espanhol, os esforços da igreja em erradicar a veneração a tais santos esqueléticos tornaram a devoção oculta durante muito tempo, até ser tornada pública recentemente.

Referências específicas à Santa Morte apareceram primeiramente nos registros coloniais espanhóis por volta de 1790, quase um século e meio depois da menção ao Rey Pascual. Um documento de 1797 dos arquivos da Inquisição, intitulado "Sobre as superstições de vários indígenas da cidade de San Luis de la Paz”, menciona a Santa Morte pela primeira vez. Focalizando o povo Chichimeca, situado no atual Estado de Guanajuato, o registro da igreja fala de trinta índios que "à noite se reúnem em sua capela para beber peiote até perderem o sentido, eles acendem velas de ponta cabeça, algumas delas

1 PERDiGÓN CASTANEDA, J. Katia. La Santa Muerte: Protectora de los hombres. Mexico City: Conaculta, 2008. p. 21.

2 FELDMAN, Lawrence H. The War Against Epidemics in Colonial Guatemala, 151-1821. Raleigh, NC: Boson Books, 199, p. 23-26. 
são pretas, eles dançam com bonecas de papel, eles chicoteiam cruzes sagradas e também uma figura da morte que eles chamam de Santa Morte, e eles amarram-na com uma corda molhada ameaçando chicotear-lhe e queimá-la se não operar um milagre." O milagre em questão era aparentemente relacionado ao controle político local e, lembrando a demolição dos santuários da Santa Morte na fronteira, ocorridos recentemente, o castigo para tais "superstições" foi a destruição da capela onde a efígie da Ossuda era mantida ${ }^{3}$.

Em seu sagaz estudo sobre santos populares latino-americanos, Frank Graziano menciona dois codinomes para o santo argentino da morte, San La Muerte, que associa o santo esquelético a Jesus. O primeiro, San Justo, e o segundo, o Senhor da Paciência, relacionam-se diretamente com a imagem do Senhor da Humildade e da Paciência, que no México e na América Central é mais conhecido como a figura de Cristo, o Juiz Justo 4 . Essa é a representação do Cristo derrotado após o açoitamento e antes de sua morte na cruz. Portanto, grupos indígenas no centro do México e no noroeste da Argentina e Paraguai fizeram a mesma associação sincrética entre as duas maiores figuras da evangelização católica - o Ceifador e Jesus. Curiosamente, o argentino San La Muerte sobreviveu à perseguição da Igreja e permanece até hoje, enquanto o mexicano Juiz Justo foi eclipsado pela sua contrapartida feminina, Santa Morte.

Em resposta à perseguição da Igreja, os devotos da Magrinha tornaram sua veneração ainda mais clandestina, a ponto de ela desaparecer do registro histórico mexicano pelos 150 anos seguintes, nos quais os mexicanos declaram sua independência da Espanha, perdem uma guerra contra os Estados Unidos e lutam na sua primeira revolução no século XX. Sem dúvida, a Poderosa continuava junto aos seus discípulos, testemunhando tais eventos e inúmeros outros, mas a sua presença só foi voltar a ser registrada a partir dos anos 1940. E a Santa Morte que ressurge a partir de então até o final do século XX é quase exclusivamente a Poderosa Senhora do Amor, simbolizada pela vela votiva vermelha.

Quatro antropólogos, um mexicano e três americanos, mencionaram seu papel como feiticeira do amor em sua pesquisa entre os anos 1940 e

3 PERDIGÓN CASTANEDA, J. K. Op. cit., p. 33.

4 GRAZIANO, Frank. Cultures of Devotion: Folk Saints of Spanish America. New York: Oxford University Press, 2007. p. 78. 
1950. Juntamente com Frances Toor e Oscar Lewis, Gonzalo Aguirre Beltran, no final dos anos 1940, refere-se a orações de amor para Santa Morte entre uma comunidade predominantemente de descendentes de africanos no Estado de Guerrero, na costa do Pacífico. Com as referências de Isabel Kelly e Oscar Lewis ao seu papel na mágica do amor, fica evidente que pelo final dos anos 1950 a cobertura geográfica da Menina Linda é extensa, se não plenamente nacional. Toor e Lewis redescobriram a santa da morte na Cidade do México, Aguirre a encontrou na costa sul do Pacífico e Kelly cruza com suas orações amorosas nas partes norte e central do México.

Em pesquisas realizadas nas décadas de 1960 e 1970, foi descoberta a devoção à santa em outros lugares do país. Em seu livro Mitos y magos mexicanos, Maria de la Luz Bernal é uma das primeiras pesquisadoras do período a documentar a devoção organizada à Careca (La Pelona). Ela escreve sobre grupos de mulheres vestidas de preto, que se ajoelhavam diante do altar da santa esquelética, segurando velas acesas, cantando em uníssono orações para a dominação de homens em suas vidas. Com gritos de "Santíssima Morte, torture-o, mortifique-o", as devotas buscavam a ajuda sobrenatural da Poderosa para controlar seus maridos e namorados errantes ${ }^{5}$.

Enquanto isso, devotos no Estado central de Hidalgo iniciaram o que parece ter sido a mais antiga devoção a Santa Morte. Como os santos esqueléticos sincréticos, o Juiz Justo, Rey Pascual e San La Muerte, São Bernardo (Clairvaux), da pequena cidade de Tepatepec, é a imagem do homem santo medieval francês que os católicos associaram com a figura esquelética da morte. Uma das mais antigas e exclusivas representações da Santa Morte é uma estátua de madeira, que agora é venerada no templo da família Cruz, tem cerca de 4 pés de altura e é geralmente vestida de rainha com um robe de cetim, uma coroa e um cetro em sua mão esquerda. Diferente da maioria das estátuas da santa, que a retrata de pé, nesta ela está sentada em uma cadeira de madeira. Particularmente impressionante é a sua face carnuda, com uma boca alongada que parece estar costurada.

A família Cruz aparentemente tinha a imagem de 200 anos em sua posse por diversas gerações, datando pelo menos desde o final do século XVII. A matriarca octogenária da família relatou que seus tataravós costu-

5 BERNAL, Maria de la Luz. Mitos y magos mexicanos. Mexico City: Grupo Editorial Gaceta, 1982. p. 27. 
mavam emprestar a imagem para as procissões da Semana Santa, na qual ela ficava sentada em uma carroça juntamente com as imagens de Cristo do Santo Sepulcro e da Virgem Maria. Acreditando ser a imagem de São Bernardo, devotos desfilavam com a estátua pela cidade no dia 20 de agosto em celebração à festa do santo. Embora os devotos não mais desfilem com ela na Semana Santa, eles continuam a celebrar a mesma festividade de agosto. Longe do olhar público, a santa esquelética fica a maior parte do seu tempo no santuário familiar no lar dos Cruz, onde muitos vizinhos a veneram.

Em uma reviravolta estranha de eventos, em algum momento dos anos 1950, um padre local da cidade invadiu a casa dos Cruz e roubou-lhes a efígie. Alegando que os devotos rezavam para a estátua com propósitos malignos, tais como assassinatos, o clérigo levou a estátua para sua igreja paroquial, a principal de Tecatepec, onde ele a exibiu para o público em uma capela lateral próxima à imagem da Virgem de Guadalupe! Conforme a matriarca, o padre pediu auxílio de seu sobrinho, que era parente do marido de Dona Cruz. Parece que os dois esperavam lucrar com o grande número de doações que "São Bernardo" lhes traria. Por mais de 40 anos, Dona Cruz e o resto da família foram forçados a venerar sua santa roubada no seu próprio cativeiro ${ }^{6}$.

Para a família Cruz, o retorno de sua santa sequestrada em 2000 era um milagre. Dona Cruz afirmou enfaticamente que "a imagem retornou para casa por conta própria" ". Um advogado apareceu inesperadamente na casa dos Cruz, sem que a família o tivesse contatado, oferecendo-se para trabalhar de graça em troca do retorno de sua querida santa. Em um encontro com o arcebispo do Estado de Hidalgo naquele ano, Dona Cruz prometeu a ele que não celebraria "missas" ou qualquer tipo de culto para a sua Santa Morte em sua casa. O clérigo concordou com os termos da soltura e então, após mais de três décadas de cativeiro, a santa da morte retornou ao altar da família. Pelos últimos dez anos, a capela da família Cruz tornou-se um dos santuários mais populares da Santa Morte no México e nos Estados Unidos, ficando atrás somente do santuário de Dona Queta, em Tepito. Todos os anos, em meados de agosto, milhares de mexicanos e até mesmo estrangeiros fazem peregrinação para pedir por bênçãos de uma das mais antigas imagens existentes da Poderosa.

6 PERDIGÓN CASTANEDA, J. K. Op. cit., p. 127.

7 PERDIGÓN CASTANEDA, J. K. Op. cit., p. 128. 


\section{Os devotos da Morte}

É precisamente à sua reputação como milagreira rápida e eficaz que se deve o crescimento meteórico de seu culto desde 2001. Um breve perfil dos devotos da Santa Morte traz à luz sua tremenda popularidade. Como seu culto é geralmente informal e desorganizado e tornou-se público somente há dez anos, é impossível saber exatamente quantos mexicanos e imigrantes mexicanos e da América Central nos Estados Unidos estão entre seus devotos. Outro grande pioneiro devocional, "Pai" David Romo, fundador da primeira igreja de Santa Morte, na Cidade do México, disse a mim e a membros da imprensa mexicana, em entrevistas separadas, que cerca de cinco milhões de mexicanos veneram o Anjo da Morte. Quando o questionei sobre como ele chegou a tal número, ele explicou que está em contato com os crentes no México e nos Estados Unidos, que lhe deram estimativas do tamanho do culto em suas cidades e regiões.

O fato de cerca de que cinco por cento da população mexicana, composta de 100 milhões de habitantes, pudesse ser devota da santa não parece absurdo perto de outra evidência de sua popularidade: as vendas de sua parafernália (velas votivas, figurinos, cartões de oração etc.) nas milhares de lojas (hierberias e tiendas esotericas) e barracas de mercado que vendem artigos religiosos, poções, pós mágicos e ervas medicinais por todo o México e em muitas cidades grandes dos Estados Unidos reduzem as vendas dos artigos de outros santos.

Um dono de loja após o outro me disse que por volta dos últimos cinco anos seus clientes compraram mais produtos da Santa Morte do que qualquer outra coisa, incluindo os artigos de São Judas Tadeu, um dos santos mais populares do país. Em Morelia, Guillhermina, cujo pai possui três lojas esotéricas na cidade, afirmou que desde 2004 a Ossuda contabilizou cerca de metade do total de vendas em seus três estabelecimentos. Ela ocupou mais estantes e espaços que qualquer outro santo das dezenas de lojas e barracas que visitei nos verões de 2009 e 2010. E os vendedores de rua que vendem uma gama colorida de bens aos motoristas parados no trânsito, esperando para cruzar a fronteira dos Estados Unidos, oferecem muito mais figurinos da Santa Morte do que de qualquer outro santo, mesmo de Guadalupe. Finalmente, o culto mensal, denominado "rosário", atrai muitos milhares de devotos ao santuário localizado no violento e decadente bairro de Tepito, na Cidade do México. 
Pelos últimos cinco anos, a Ossuda tem acompanhado seus devotos em suas viagens cruzando a fronteira dos Estados Unidos e estabeleceu-se ao longo da fronteira de duas mil milhas e nas cidades com comunidades de imigrantes mexicanos. Não de forma surpreendente, é em cidades de fronteira, como El Paso, Brownsville e Laredo, que a evidência de seu culto é mais forte. Sua imagem de Ceifadora, na forma de decalques em preto e branco, situa-se nas janelas traseiras (quase sempre escurecidas) de inúmeras picapes e SUVs, anunciando tanto a devoção de seus ocupantes como a sua própria presença crescente. Nas mesmas lojas de parafernália religiosa encontradas no México, comerciantes ao longo da fronteira movimentam um intenso negócio ao vender incensos da Santa Morte, loções e, sobretudo, velas votivas. Quase a maioria da cobertura televisiva sobre o rápido crescimento do seu culto nos Estados Unidos foi fornecida por estações locais dessas cidades fronteiriças. Tais notícias tendem a ser sensacionalistas, explorando os supostos laços entre a Santa Morte com tráfico de drogas, assassinatos e até sacrifício humano.

Na parte norte da área fronteiriça, a Madrinha ouve as orações e petições dos mexicanos e, em menor medida, de imigrantes da América Central, que lhe pedem para interceder a favor do seu sucesso na nova terra. Los Angeles, Houston, Phoenix e New York, com suas grandes comunidades mexicanas e de imigrantes da América Central, são locais evidentes para se encontrar a Poderosa protegendo seus fiéis. Lar da maior comunidade de imigrantes mexicanos nos Estados Unidos, Los Angeles é a Meca americana do culto da santa esquelética. Além de pelo menos duas lojas de artigos religiosos que carregam seu nome (Botanica Santa Morte e Botanica de la Santa Morte), a Cidade dos Anjos oferece aos devotos dois templos onde podem agradecer ao Anjo da Morte pelos milagres alcançados ou pedir a ela saúde, prosperidade e amor. A Casa de Oracion de la Santissima Muerte e o Templo Santa Morte são os dois únicos templos dedicados ao seu culto nos Estados Unidos. O último oferece "missas", casamentos, batismos, rosários e cultos de cura. O seu templo virtual, inspirado em motivos góticos $(<$ www.templosantamuerte.com $>$ ) transmite música devocional e algumas de suas missas. Curiosamente, a maior parte do conteúdo do site bilíngue está em inglês.

Em Houston, onde vivi por onze anos, ainda não existe nenhum lugar público de adoração, mas a Irmã Branca aparece em velas votivas 
e em pacotes de incenso, dentre outros produtos, em centenas de estantes em supermercados locais e lojas de artigos religiosos. Em junho de 2009, enquanto eu saía do estacionamento do supermercado Fiesta, voltado para o público latino, em especial mexicano, no centro de Houston, avistei uma estátua branca da santa medindo quatro pés de altura, sendo levada no bagageiro de um antigo modelo de picape Ford. A janela traseira pintada da caminhonete exibia um decalque de sua Santíssima Morte. Tal como em Los Angeles, os devotos da Bayou City (cidade do rio pantanoso, um dos apelidos de Houston - NT) podem escolher entre pelo menos três lojas de artigos religiosos que possuem o nome da Santa Morte.

Para além dessas grandes cidades, devotos e curiosos podem até encontrar a santa esquelética em cidades com comunidades relativamente diminutas de imigrantes mexicanos, tais como em Richmond, no Estado de Virginia (norte dos Estados Unidos). Nos últimos cinco anos, a Ossuda acompanhou dezenas de milhares de seus seguidores devotos através da fronteiras até as cidades grandes e municípios menores dos Estados Unidos, por onde eles decidiam tentar iniciar uma nova vida por seus próprios meios.

Santa Morte possui devotos seguidores de todos os estratos sociais, tais como estudantes de ensino médio, donas de casa de classe média, motoristas de táxi, traficantes de droga, políticos, músicos, médicos e advogados. Rodrigo é um bem-sucedido advogado, de pouco mais de vinte anos, que encontrei no famoso santuário de Dona Queta, em Tepito. Ele foi para lá com uma vela branca a fim de agradecer à Menina Branca por libertá-lo de sequestradores. Lá também se encontrava Claudia, uma contadora de trinta e poucos anos, que se tornou crente dos poderes milagrosos da santa na mesa de cirurgia. Antes de sua operação de pulmão infeccionado, seu cirurgião deu a ela uma estatueta da Poderosa e sugeriu que Claudia evocasse seus poderes de cura. Tal como vários que vão ao santuário de Tepito, Claudia estava lá para agradecer à Santa Morte por ter sido curada de uma enfermidade.

Por conta de sua associação com o crime organizado, especialmente com traficantes de droga e sequestradores, além da condenação por parte das igrejas Católica e protestantes, crentes mais abastados tendem a manter sua devoção no âmbito privado. De fato, desde sua primeira menção em registros históricos, em 1797, até 2002, Santa Morte era venerada de forma clandestina. Altares domésticos são onde os devotos prósperos preferem realizar os rituais que evocam a santa para agir em seu favor. De 
acordo com o intelectual e romancista mexicano Homero Aridjis, o Anjo da Morte possui uma ampla gama de seguidores entre os políticos de alto escalão, estrelas de cinema, senhores da droga e mesmo na alta cúpula da Igreja Católica nos anos 1990, antes de seu culto tornar-se público! Aridjis transformou em ficção seu relato de ter participado de uma festa de aniversário orgíaca em 2000, com tais devotos, no seu mais recente romance, La Santa Morte 8 . O casamento da estrela da TV mexicana Niurka Marcos, em 2004, corrobora as alegações de Aridjis. A cerimônia foi conduzida por David Romo, fundador da primeira igreja de Santa Morte, em uma fazenda exclusiva situada fora da cidade do México9.

Ainda assim, em um país com nível educacional que vai até a oitava série, a grande maioria de devotos se encontra entre os motoristas de táxi, prostitutas, vendedores de rua, donas de casa e criminosos. Uma devota típica é a madrinha do culto da Santa Morte, Dona Queta. Antes de seu ato histórico de exibir uma estátua de tamanho real da Ceifadora na frente de sua casa no Dia de Todos os Santos, em 2011, Enriqueta Romero complementava a renda familiar vendendo quesadillas para vizinhos e para quem passasse na rua. Sempre trajando um avental quadriculado azul e branco, que é praticamente o uniforme das mulheres trabalhadoras no México, Dona Queta não possui mais do que nível escolar básico. Seu colorido sotaque espanhol da classe trabalhadora, apimentado de vulgaridades, reflete o violento bairro de Tepito, na Cidade do México, onde as gangues de drogas, sequestradores, prostitutas e contrabandistas mandam nas ruas. Dona Queta começou sua cerimônia de rosário da Santa Morte em agosto de 2009, com um aviso para que os fiéis retornassem rapidamente para suas casas ao final do ritual, se não seriam importunados por "todos os malditos ladrões e bandidos das redondezas". Um de seus sete filhos cumpriu pena na prisão e sua soltura foi atribuída por Dona Queta à intervenção divina da sua Menina Linda (la nina hermosa).

A jovem desempregada de dezenove anos Raquel, que largou os estudos do ensino médio e que mora na periferia da Cidade do México, é outra devota típica. Aparentando uma magreza anoréxica quando a entre-

8 Homero Aridjis, entrevista com o autor em 16 janeiro de 2011.

9 FERRIS, Susan. Saint Death Calls to the Living in Mexico City. Atlanta Journal-Constitution , 9 de março de 2004; David Romo, entrevista com o autor em 5 julho de 2009. 
vistei no santuário de Dona Queta, Raquel tornou-se devota depois que a Poderosa apareceu no meio de uma briga de gangues e a puxou uns poucos passos, antes que um canivete atingisse seu estômago. Raquel, tal como muitos outros crentes, estava no famoso santuário de Tepito com uma vela votiva dourada de Santa Morte. Antes de conversar comigo sobre sua devoção, ela colocou a vela acesa na base do altar junto a muitas outras e pediu por um milagre de emprego à grande estátua da santa esquelética por trás do vidro de proteção.

De acordo com meus registros, Raquel se enquadra no perfil normal dos devotos em termos de gênero e idade. Diferente dos Estados Unidos, o México é um país jovem, com faixa etária média de 24 anos. Os padrinhos do culto (Dona Queta e David Romo) confirmam que a maioria dos crentes são adolescentes e jovens adultos, entre seus vinte e trinta anos. De mesma forma, ambos afirmam que veem mais mulheres e garotas do que homens em seus santuários. Pai Romo disse que mais de dois terços dos que participam semanalmente dos cultos em sua igreja são mulheres. Durante os muitos dias em que permaneci no santuário de Dona Queta entrevistando devotos, notei também que havia cerca do dobro de garotas e mulheres que vinham ver a santa vestida de forma régia.

Contudo, os cultos mensais de rosário de Dona Queta eram praticamente uma ocupação masculina. Não mais que vinte por cento dos devotos presentes no culto de agosto de 2009 eram mulheres. A explicação mais provável para a ausência feminina é a notoriedade de Tepito como o bairro mais violento e criminoso da capital do México. As palavras de alerta de Dona Queta no início do culto só confirmam tais medos. A preocupação com a segurança no verão de 2009 fez a madrinha do culto mudar os cultos do fim da noite para o fim da tarde. Dessa forma, os devotos poderiam sair antes do anoitecer, evitando os assaltantes noturnos do bairro.

\section{A morte do crime e castigo}

De forma não tão paradoxal, a Santa Morte possui um apelo especial para assaltantes e outros que vivem à margem das leis mexicana e americana. Afinal de contas, as próprias origens do culto público estão 
ligadas ao crime. A efígie de larga escala da santa de Dona Queta, que é objeto de devoção para dezenas de milhares de chilangos (gíria que nomeia os residentes da Cidade do México), foi um presente para ela dado por um de seus filhos, que agradeceu à Poderosa por sua rápida soltura da prisão por um crime não especificado. Dentre as mulheres enfermas e grávidas, "aqueles na prisão" são o objeto de orações coletivas especiais no culto mensal do rosário.

Em penitenciárias mexicanas, texanas e californianas, o culto da Ossuda é tão difundido que em muitos ele é o objeto principal de devoção, superando Guadalupe e até São Judas, o padroeiro das causas perdidas. Meu sobrinho, Roberto, trabalhou como guarda na prisão estadual de segurança máxima em Morelia nos últimos três anos. Em junho de 2009, Roberto não só detalhou a devoção à Santa Morte entre os prisioneiros, mas também pintou um retrato de um sistema penal inteiro envolvido em sua veneração. Das 150 celas na prisão, Roberto estimou que aproximadamente 40 presos ergueram altares feitos à mão à Poderosa, a quem confiam que possa libertá-los mais cedo. Carreiras de cocaína, uísque feito na prisão (turbo), cigarros e maconha estão entre as oferendas mais comuns nesses altares. Há oferendas também tatuadas nas costas, peito e braços dos prisioneiros, num trabalho feito por três detentos que cobram entre quatro e trinta dólares por tatuagem. De acordo com Roberto, as tatuagens do Anjo da Morte são mais populares do que de qualquer outro santo.

Além dos que cumprem pena, muitos guardas, assistentes sociais e até advogados pertencem ao culto da Santa Morte. Roberto disse que dez de seus 48 colegas são devotos e que não é incomum ver advogados e assistentes sociais na prisão exibindo medalhões dourados da santa em seu peito. Em um ambiente de trabalho tão perigoso, cheio de drogas e armas rústicas, pode-se imaginar o apelo da proteção sobrenatural oferecida pela Poderosa. Em menos de uma década, ela se tornou a santa padroeira do sistema penal mexicano e é também popular de uma forma crescente nas prisões americanas, em especial no sudoeste e na Califórnia.

Muitos daqueles que correm o risco de serem pegos por seus crimes pedem à Magrinha por proteção sobrenatural de seus inimigos. A vela votiva da Santa Morte que exclama "lei, fique longe!" (geralmente impressa de forma bilíngue em espanhol e inglês) é encontrada nas lojas por todo o México e Estados Unidos. Da mesma forma, "morte aos meus 
inimigos", a vela de sete cores, vende bem entre aqueles cujo trabalho os coloca em contato direto e constante com a morte. De fato, mesmo antes do crescimento astronômico do culto iniciado por Dona Queta, o primeiro contato que os mexicanos tiveram com a Santa Morte foi nas páginas policiais dos tabloides diários. Depois de sequestrar mais de vinte pessoas na década de 1990 e coletar mais de 40 milhões de dólares de resgate, Daniel Arizmendi Lopez foi preso em sua casa em agosto de 1998. Conhecido com o Cortador de Orelhas (Mocheorejas), por seu horrível hábito de enviar as orelhas cortadas de suas vítimas para seus familiares, Arizmendi atraiu mais atenção nas manchetes pela sua devoção à então quase desconhecida santa da morte. Os agentes da lei mexicanos descobriram um altar para a Santa Morte em sua casa e, curiosamente, permitiram que levasse sua estatueta para a prisão, onde pudesse continuar sua devoção atrás das grades ${ }^{10}$. Assim, três anos antes de Dona Queta começar seu culto público, um dos mais famosos sequestradores na história do país apresentou de forma violenta a Santa Morte para o público mexicano.

Desde então, a Irmã Branca tornou-se presença regular nas páginas policiais dos tabloides mexicanos e frequentemente aparece nas reportagens das redes locais de TV na fronteira. As polícias do México e, crescentemente, dos Estados Unidos descobrem rotineiramente altares e parafernália devocional da Santa Morte nas casas e em posse de criminosos suspeitos, especialmente traficantes. A polícia mexicana prendeu Angel Jacome Gamboa em março de 2009, acusando-o de assassinar doze policiais em Rosarito Beach, a mando de seu renomado chefe, um dos maiores líderes do crime organizado de Tijuana. Uma das armas do assassino mostradas à imprensa era um revólver com uma imagem dourada da Santa Morte gravada em relevo na coronha. A santa da morte não poderia ter ficado mais perto do matador à medida que ele apertava o gatilho e despachava suas vítimas para o seu abraço ossudo.

A violência também visitou as maiores figuras no culto. Nascido e criado em Tepito, o Comandante Pantera era uma estrela em ascensão entre os seguidores da Irmã Branca. Na periferia miserável da Cidade do México, em Ecatepec, o jovem líder de culto e motociclista entusiasta, conhecido

de 1998.

10 La Revista Peninsular. Detienen al peligroso secuestrador Daniel Arizmendi. 18 de agosto 
também como Jonathan Legaria Vargas, ergueu uma estátua preta gigante de 72 pés de altura da santa. Mesmo antes de a construção terminar, a efígie gigantesca e seu patrono viram-se em uma controvérsia. Funcionários municipais, alegando que ela violava as leis de zoneamento, ordenaram que o Comandante Pantera removesse a impressionante estátua, que podia ser vista de uma das maiores avenidas que atravessava a cidade. Ignorando as reclamações de pais na vizinhança, que diziam que suas crianças estavam tão assustadas com a imensa santa esquelética que não podiam dormir à noite, Legaria não só recusou a acatar as ordens municipais, como sugeriu que a violência poderia emergir se a polícia tentasse retirar à força a estátua. Tanto a mídia mexicana como a americana deram ampla cobertura para a controvérsia e seu carismático protagonista. Devotos e residentes curiosos foram ao terreno do templo de Ecatepec para olhar em primeira mão a "maior estátua de Santa Morte do mundo".

Uma violência diferente da que o Comandante Pantera tinha em mente o pegou de surpresa no início da manhã de 31 de julho de 2008. A Ossuda veio para um dos seus devotos mais proeminentes apenas alguns minutos após ele terminar seu programa de rádio de fim de noite dedicado à sua devoção. Vários atiradores alvejaram o Cadillac Escalade de Legaria's com quase duzentas balas, cinquenta das quais mataram na hora o líder de culto de 26 anos. A Santa Morte poupou suas duas acompanhantes, que foram criticamente feridas, mas sobreviveram. Tal matança é típica de assassinatos relacionados a drogas, mas, como muitos casos de homicídio no México, mais de um ano se passou sem nenhuma resolução ${ }^{11}$.

No início de 2007, três homens algemados foram executados a mando do Cartel do Golfo em frente a uma imagem da Santa Morte, na periferia de Nuevo Laredo. Após alguns meses, David Romo tratou de desvincular qualquer associação entre as execuções e o culto à santa. Para isso, desvelou uma imagem radicalmente nova da Santa Morte em seu templo, no distrito de Morelos, na Cidade do México. Uma estátua em tamanho real de um anjo feminino de cabelos castanhos, com uma compleição de porcelana e asas de penas, substituiu a tradicional santa esquelética no santuário principal. Romo batizou o novo ícone de "Anjo da Morte" e pediu aos membros da

11 NAVARRO, Juan Manuel. Sepultan hoy a líder del templo de la Santa Muerte. El Universal, 1 de agosto de 2008. Disponível em: <http://www.eluniversal.com.mx/notas/526952.html>. 
igreja que substituíssem suas imagens da Ossuda por esta, a nova e linda face da morte. Após três anos, a igreja permanece repleta de figuras, pinturas e velas votivas com a forma esquelética da santa, enquanto que as barracas de venda, dentro e fora do templo, oferecem quase somente imagens da Ceifadora retratada em sua forma tradicional! Romo culpou os vendedores pela falta de parafernália do Anjo da Morte, que não estariam interessados em oferecer a nova imagem enquanto a antiga vendesse tão bem.

\section{Vela de sete cores da morte}

Enquanto não há como negar seu apelo especial para aqueles que vivem, trabalham e morrem no mundo criminoso, incluindo agentes da lei, minha pesquisa tem como objetivo considerar a santa da morte em sua fascinante totalidade. Se focalizássemos somente na vela votiva preta, representando o lado obscuro da devoção, estaríamos ignorando as velas mais populares - vermelha, branca e dourada - que são acesas pelos devotos para propósitos muitos diferentes dos relacionados ao crime e castigo.

Com suas sombras de arco-íris, a poderosa vela de sete cores captura precisamente a identidade multicolorida da Poderosa. Essa vela, dentre as mais vendidas, é oferecida por devotos quando estão à procura de intervenção sobrenatural em múltiplas frentes. Por exemplo, a que comprei em Morelia é estruturada dentro de uma borda de quatorze crânios brancos e, à semelhança/retrato da Santa Morte, na parte da frente do vaso da vela possui balanças equilibradas, representando justiça e estabilidade. Em caracteres grosseiramente gotejados, lembrando mensagens escritas a sangue nos muros de filmes de horror americanos, na base da vela, logo abaixo de sua túnica, lê-se MORTE AOS MEUS INIMIGOS (MUERTE CONTRA MIS ENEMIGOS).

A oração à Linda Menina na parte de trás da vela exibe uma petição específica para trazer de volta um marido ou namorado que se foi e um pedido geral para proteção e benefício. Tendo em mente companheiros infiéis, o início da oração segue-se: "Quero que a senhora (Santa Morte) entregue (Fulano de Tal) humilde aos meus pés para que ele cumpra as suas promessas". A oração termina em grande nível: "Peço que a senhora 
concorde em ser minha padroeira e que me conceda todos os benefícios que Lhe pedir até meu último dia, hora e minuto." Em um único objeto ritualístico das cores do arco-íris, a Madrinha despacha justiça, restaura o equilíbrio, neutraliza os inimigos, devolve homens infiéis e concede uma miríade de favores. A consideração ao espectro completo de cores das velas votivas, e não somente da cor preta, permitirá um rico entendimento da ascensão dramática do culto da Santa Morte na última década.

A vela marrom serve para assuntos de esclarecimento, discernimento e sabedoria, ainda que esta não esteja entre as velas mais populares. $\mathrm{O}$ santo argentino San La Muerte parece dedicar muito mais tempo e energia que a Santa Morte para ajudar seus devotos a encontrar objetos roubados e perdidos. Membros do culto mexicano e da América Central parecem não apelar à santa para a recuperação de pertences perdidos. Contudo, quando o fazem, uma vela cor de café é a recomendada para o serviço.

Em contraste com a vela marrom, a vela branca é uma das mais vendidas nas barracas de mercado e nas lojas "esotéricas". É também a vela mais comum nos santuários do México, tais como os de Dona Queta e de David Romo. Pureza, proteção, gratidão e consagração são os mais frequentes atributos da vela sem cor, isso combinado com o fato de que o esqueleto da Ossuda e de dois de seus apelidos mais comuns referirem-se à ausência de cor (Menina Branca e Irmã Branca).

A vela preta está associada a trabalhos de vingança, dano e proteção contra a "magia negra" e os inimigos. Ela é a que mais demora a vender e raramente aparece em lugares devocionais nas beiras de estradas e calçadas. Obviamente, por conta de sua associação entre o público geral com a "magia negra" e bruxaria, muitos devotos que regularmente ou até ocasionalmente usam essas velas provavelmente preferem acendê-las na privacidade de seus lares, longe de olhos críticos. Não obstante, nos muitos altares domésticos que visitei pessoalmente e nos que vi por fotos, incluindo locais de crimes, a mais negra das velas está entre as menos populares. De qualquer forma, nas economias religiosas competitivas do México e dos Estados Unidos, a vela votiva preta serve como um dos produtos do culto mais exclusivos.

Devotos que buscam neutralizar inimigos, se vingar de erros imaginários e reais ou proteger um carregamento de cocaína destinada a Houston ou Atlanta podem tentar alistar a Santa Morte para sua causa ao fazer-lhe uma oferta de vela preta. Criados como católicos, praticantes ou 
não, a maioria dos devotos sente-se muito mais confortável ao pedir à santa popular, que não vai julgá-los para realizar milagres não cristãos do que dirigirem-se aos santos tradicionais que, provavelmente, recusarão uma bênção a um carregamento de drogas ou outros atos ilícitos.

$\mathrm{O}$ vermelho, junto com o branco e o preto, figura entre uma das cores históricas do culto e é uma das velas votivas que mais vendem, segundo minha pesquisa com os comerciantes nos dois países. Como pesquisador, deparo-me com surpresas intrigantes ao longo do trabalho de campo. Antes de partir para o México, no verão de 2009, não fazia a menor ideia da importância suprema das velas vermelhas e do propósito a que serviam. Nada do que havia sido publicado dentro e fora da academia sobre a Santa Morte dava pista alguma sobre o seu papel como doutora sobrenatural do amor, especialmente para mulheres mexicanas e da América Central. Entrevistas com devotos, líderes de culto e vendedores de artigos religiosos revelaram uma Poderosa que provavelmente gasta mais tempo atendendo aos assuntos do coração do que qualquer outro assunto. Rosa, uma faxineira de 32 anos, de Patzcuaro, Michoacan, por exemplo, coloca uma vela vermelha acesa no seu altar doméstico para que a Irmã Branca mantenha seu ex-marido abusivo longe dela e de seus quatro filhos.

Simbolizando paixão, amor e fortes emoções, a cera vermelha queima em altares de Chiapas a Chicago, onde amantes dispensados e namoradas ciumentas pedem à santa, que está geralmente vestida de noiva, para consertar seu coração partido ou dobrar e trazer de volta seu marido ou namorado inconstante. De fato, as primeiras referências escritas à santa esquelética no século XX a mencionam nesse contexto. No livro, Treasury of Mexican Folkways, publicado em 1947, Francis Toor menciona diversas orações à Santa Morte envolvendo a domesticação de homens que se comportavam mal.

No clássico estudo antropológico de Oscar Lewis, publicado no final dos anos 1950, The Children of Sanchez, Marta, residente em Tepito, diz ao antropólogo americano que sua irmã Antonia tinha pedido à Santa Morte o fim dos casos extramaritais de seu marido Crispin. "Da primeira vez que minha irmã Antonia me contou sobre os desvios de Crispin, ela me aconselhou para rezar para a Santa Morte à meia-noite por nove noites seguidas, com a foto de Crispin e uma vela feita de sebo na minha frente. Ela prometeu que, antes da nona noite, meu marido esqueceria outras mulheres. Comprei a oração de novena de um homem que me vendeu essas coisas no 
bairro e a decorei." A oração que Antonia recitou é a mesma citada acima, a petição para o retorno do marido "humilde aos meus pés".

Além das três cores tradicionais, as velas douradas de Santa Morte competem com as velas brancas pelo segundo lugar em vendas nas barracas de mercado e lojas de produtos religiosos e são, junto com as velas sem cor, a cera colorida mais comum em santuários públicos, incluindo os de Dona Queta e David Romo. O dourado é a cor do dinheiro, da prosperidade e da abundância no culto. Sofrendo as demissões e subempregos na pior recessão econômica dos Estados Unidos e México desde a Grande Depressão, centenas de milhares, se não milhões, deixam uma vela votiva dourada aos pés ossudos da Santa Morte em troca de bênçãos financeiras. Muitos devotos no santuário histórico de Dona Queta estão lá com velas douradas em mãos para pedir emprego à Poderosa.

A santa, que tem a reputação de "quebrar o galho", tornou-se a padroeira oficial de numerosos donos de pequenos negócios por todo o México e em partes dos Estados Unidos. Yolanda, de 34 anos, clamou à Madrinha ajuda para começar seu próprio salão de beleza na Cidade do México e até ergueu um altar no seu estabelecimento para garantir um fluxo constante de clientes. Yolanda é tão grata a sua padroeira que, a cada dois anos, ela contrata um conjunto de mariachis por 160 dólares para fazer um tributo musical à Magrinha no culto mensal do rosário. Curiosamente, a enérgica cabeleireira pediu tanto a Guadalupe quanto a São Judas para auxiliá-la a montar seu negócio antes de recorrer à Santa Morte. Yolanda disse que sua nova padroeira era mais confiável que os outros. A santa não atua somente como agenciadora de empregos e filantropa divina, mas também ocupa uma importante posição na economia comercial, na qual as vendas de seus retratos em objetos ritualísticos e mesmo camisetas, agasalhos e tênis representam um negócio multimilionário.

Além de atuar no mercado, a Santíssima Morte realiza um papel indispensável como curandeira divina. Em meu trabalho anterior sobre Pentecostalismo e Catolicismo Carismático, mostrei como a cura divina é a força motora por trás do impressionante crescimento dessas formas de cristianismo centradas no Espírito Santo ${ }^{12}$. De forma similar, um dos

12 CHESNUT, R. Andrew. Competitive Spirits: Latin America's New Religious Economy. New York: Oxford University Press, 2003. 
grandes paradoxos do culto é que uma santa que personifica a própria morte é encarregada de preservar e prolongar a vida por meio de seus incríveis poderes curativos. Aqui a Santa Morte não é a Ceifadora que colhe as almas com sua foice, mas a Mãe de todos os médicos, consertando corpos partidos e ossos fraturados. A vela roxa é a que simboliza essa cura sobrenatural.

Uma disparidade curiosa do culto reside entre a grande ênfase depositada pelos devotos sobre a cura e a relativa ausência de velas cor de lavanda nos santuários e nas lojas. Pode ser que seja uma das cores mais novas que ainda está para ser mais adotada pelos fiéis ou, ainda, que muitos dos que buscam uma cura milagrosa preferem a cobertura extensa da vela de sete cores, que inclui o roxo no seu arco-íris. Qualquer que seja o caso, a vela púrpura iluminará os caminhos nos quais a santa da morte age para preservar e estender a vida humana no contexto dos agentes patológicos da pobreza no México e Estados Unidos.

A Santa Morte, no espírito do tempo, é um formidável ser multitarefas. Se os papéis de médica, agenciadora de empregos, doutora do amor e anjo vingador não são suficientes, ela também serve como a padroeira da justiça. Devotos com problemas legais e que buscam uma solução justa para seus problemas oferecem velas devocionais verdes para a Poderosa, que é geralmente representada com as balanças da justiça em sua mão direita. Ela não exerce tanto o papel de juíza, mas de advogada sobrenatural. Os juízes julgam, e um dos grandes atrativos da santa entre os fiéis é sua atitude de não julgamento. Como advogada divina, Santa Morte é mais interessada em conseguir o melhor acordo para seus clientes devocionais do que estabelecer sua inocência ou culpa. Em um país onde a justiça e a igualdade perante a lei são frequentemente um artigo em falta, milhões de mexicanos sentem que somente pela intervenção divina eles teriam uma chance de resolver seus problemas legais. E se sua defensora sobrenatural não está apta a ajudá-los a vencer o seu caso, devotos podem encontrar consolação na ideia de que mais cedo ou mais tarde os perpetradores da injustiça, junto com todos os mexicanos, sentirão a foice igualadora da Ceifadora.

Obviamente, é a vela de sete cores que melhor representa esses grandes poderes multitarefas da Santa Morte. É fácil entender por que essa, a mais nova das velas coloridas, é uma das que melhor vendem, juntamente com a vermelha, a branca e a dourada. Provavelmente baseada na vela dos sete poderes (siete potencias) da Santería, a principal religião derivada da 
diáspora africana em Cuba, o instrumento devocional com as cores do arco-íris reúne todos os poderes da santa em uma só vela. Em um país assaltado por uma das piores recessões econômicas em décadas, violência pandêmica, uma mortal guerra contra as drogas, muitos mexicanos voltam-se para a Madrinha para ajudá-los em múltiplas frentes.

Recebido em maio de 2011. Aprovado em agosto de 2011. 